\title{
A Técnica do Ensino
}

\section{A. de Sampaio Dória}

Ha mais de quarenta anos, comecei a carreira do magistério numa escola primária. Por longo tempo me atraiu o ensino secundário, até à cátedra de direito, que professo, na Universidade de São Paulo. Tempo houve, de 1915 a 1926, em que, após árduo concurso, ensinei a ensinar, por dever de ofício, na Escola Normal desta cidade. Foi por esta época que, animado pela minha já então longa experiência, publiquei, sobre a técnica do ensino, uma doưtrina, de cujos principios nada tenho que desdizer.

Tentarei, sob fórma nova, reproduzi-la, aqui, em resumo.

\section{Confusão entre método lógico e método didático}

Começava eu, então, e reitero hoje, por prevenir a confusão correntia entre método didático e método lógico, entre o que se ajusta ao ensino, e o que se aplica na investigação científica. Ouve-se, a cada passo, recomendar-se, para o ensino, ora o método indutivo, ora o método dedutivo. Tenho, no entanto, por acertado que nem um nem outro cabem no ensino. São ambos métodos lógicos; nunca, propriamente didáticos.

Para que o fossem, seria preciso confundir, primeiro, investigação científica com ensino.

Mas as realidades observaveis desfazem, de todo, a confusão. 
Na investigação, o que se leva em propósito, é decifrar mistérios da natureza. A verdade, a que o investigador atinja, salvo acasos felizes, só a poderá lograr, se orientar o seu trabalho pelos métodos da concordancia, da diferença, das variações concomitantes, tão bem precisados por Stuart Mill. Foi, por exemplo, entre inúmeros o caso de Pasteur, cujas observações e experiencias, feitas sob a inspiração destes métodos. lhe permitiram desvendar profundos segredos da criação, proporcionando a todos os homens perspectivas incomensuráveis de saude, riqueza e bem estar.

No ensino, o fenômeno é inteiramente outro. Em primeiro logar, o que se tem por mira, não é descobrir verdades. Estas já estão, ou devem estar sabidas pelos que ensinam. Os alunos, sim, as ignoram. Mas não são eles que vão ensinar; vão aprender.

Ora, se o trabalho do professor, no ensino que the cumpre, não é como o do cientista nas revelações, que empreenda, como empregar, num e no outro, os mesmos meios de ação?

$\mathrm{Na}$ investigação científica, insistamos, a finalidade $\dot{\mathrm{e}}$ a revelação do desconhecido, a inferencia de verdades que se ignoram, ou a verificação de leis que se presumem.

No ensino, porem, as leis já foram inferidas, as verdades estão sabidas por quem vái ensiná-las, nem teria senso ensinar o que desconheça. Ensinar vem a ser:

Primeiro: informar, transmitir conhecimentos, expôr fatos. Assim, por exemplo, quando o professor narra o descobrimento do Brasil, como e quando tal acontecimento se deu.

Segundo: persuadir, não apenas enunciar, mas convencer. O ensino não é só informativo. Mas persuasivo. E', por exemplo, o caso expressivo do ensino de matemática, em que o professor não se limita a formular teoremas. Mas os demonstra. As conclusões a que chegue, ou faz chegar seus alunos, podiam ter sido, ou não, proclamadas antes da prova. Mas o ensino de matemática consiste principal- 
mente em demonstrar teses, isto é, criar, nos alunos, a conviç̧ão da verdade que a tese enuncie.

Terceiro: além de expôr fatos, e persuadir da verdade, busca o ensino a formação mental, criando, nos alunos, hábitos de atenção, hábitos de lógica, hábitos de confiança em si mesmos. E, talvez mais do que a cultura, vale, na vida, o desenvolvimento da inteligencia, e a disciplina da vontade, que se promovem no ensino.

São, assim, rapidamente indicados, estes os fins do ensino: informar, persuadir e formar.

O trabalho que toca ao professor, para a realização destes propósitos, se processa, ademais, em condições diferentes das que envolvem a investigação científica. Enquanto nesta, ha, de um lado, o cientista que ignora e observa, e, do outro, a natureza ignorada, que se esquiva, no ensino, ha, de um lado, o professor que sabe e dirige o aprendizado aos alunos, e, do outro lado, os alunos que ignoram, e querem saber.

Logo, o trabalho do professor, que ensina, não é idèntico ao do cientista que investiga.

$O$ método didático recái sobre a atividade do professor ao dirigir a atividade dos alunos, que aprendem.

O método da investigação científica recái sobre a atividade do cientista, que se dirige a si mesmo, para apanhar ou verificar as leis que indaga.

Não ha, pois, motivo razoavel para a confusão, em que tanta gente incide, quando apregoa, para o ensino, o método indutivo ou dedutivo, que disciplinam a investigação científica.

Sem dúvida, a atividade dos alunos, que aprendem, se ha de inspirar tambem na disciplina lógica do raciocínio. Convém que ele observe, experimente, compare, e, por fim, infira, como se lhe incumbisse redescobrir. E, neste trabalho, se modelará nos métodos lógicos, para não malograr. 


\section{0 que é método de ensino}

Mas o método de ensino não é a disciplina da atividade do aluno. E' a disciplina da atividade do professor na direção que imprime à atividade dos alunos.

Sem delimitar precisamente o campo do método de ensino, não póde haver entendimento razoavel entre os estudiosos destes assuntos, oficiais todos do mesmo ofício.

Para certos pedagogos, o método chega a ser tudo no ensino; toda a pedagogia é didática. Outros, porém, entendem que a metodologia é um capítulo, de suma importancia sem dúvida, mas um capítulo apenas na ciencia da educação. Não é método de ensino o problema da concepção verdadeira da educação. Não é método de ensino o problema da finalidade educativa. Não é método de ensino o problema da seriação das matérias nos vários cursos. Não é método de ensino a extensão dos ciclos educativos, ou o problema dos programas. Numerosos assuntos constituem matéria para a ciência da educação. E, entre êles, a técnica do ensino.

Está o professor em uma sala, deante de uma classe que não organizou, com a tarefa de ensinar disciplina que não determinou, em horário que aceitou. A lição do dia é o número tal do programa oficial. Como deve, nestas circunstancias, proceder o professor, para que sua classe fique sabendo o assunto que vai ensinar?

Eis o âmbito do método de ensino. E' a disciplina ou a direção que o professor imprime à atividade do aluno, para que aprenda, se persuada e se forme. Pelo menos, nesta exposição, método de ensino não abrange toda a pedagogia.

\section{Empirismo didático}

Ouve-se, a cada passo, que o professor não precisa estudar o seu ofício. Alguns ha que se gabam de jamais ter aprendido didática, e, não obstante, são, sem favor, bons professores. Valem-se do bom senso, e se inspiram na sua própria experiencia. 
Certo, ha vocações para o magistério, como para qualquer outra profissão. Mas não menos certo é que a vocação, ainda a mais apuradà, não exclue nem a técnica, nem a ciência correspondente. Em consequencia de uma longa prática, póde um enfermeiro que tenha geito para lidar com doentes, ser, numa casa de saúde, excelente na pontualidade, na paciência, na técnica, e, até, em concurrencia com os clínicos, para diagnosticar e prognosticar. Mas não passará nunca de charlatão, quando metido a médico. Se, porém, este mesmo enfermeiro aliasse à sua prática a ciencia médica, outra seria, por certo, a sua segurança no diagnóstico, a sua eficiencia na cura, o seu prestígio na confiança dos enfermos.

Assim, o professor meramente empírico. Póde ser excelente na arte. Mas nada perderia em saber a ciencia do seu ofício, em eonhecer a psicologia da criança, as leis do desenvolvimento da inteligencia, a fisiologia do trabalho mental, a função social da educação, as qualidades pessoais do mestre, numa palavra: a técnica do ensino.

Mesmo o que ele sabe, sem estudos especializados, foi, talvez, obtido no vai-vem de suas experiencias, mas a custa, não raro, dos educandos. A ciencia dos métodos lhe teria poupado esforços inúteis, e, por vezes, prejudiciais aos outros.

E que custa aos que seguem o magistério, aprender a ciencia e a técnica do seu ofício?

\section{Idoneidade da ação didática}

A técnica do magistério não é fantasia de improvisadores. Mas normas objetivas, por onde se cunha a capacidade no ensinar.

O professor exerce atividade sobre a infancia e a mocidade. Mas essa atividade, longe de ser arbitrária, se disciplina, como em outra qualquer profissão.

Ora, dar o professor a conhecer, dia a dia, aos alunos a matéria do programa, e de sorte que se convençam da 
verdade no que lhes é ministrado, e desenvolvam, ainda, as suas faculdades mentais, tudo isto que é, senão interferir o professor na atividade mental dos alunos, para aprenderem? Que é tudo isto, senão, primeiramente, produzir, ou ensejar a que se produza, no cérebro dos alunos, o fenômeno do conhecimento, a aquisição de noções, a persuasão da verdade? Que é tudo isto, senão fazer perceber e raciocinar? $O$ professor tem de proceder de tal arte, que os alunos adquiram, por percepção e raciocínio, os conhecimentos das lições.

Mas já se tem pregado, sem conto de vezes, que a natureza só se deixa dirigir pelos que lhe obedecerem as leis. Qualquer intervenção do homem em fenômeno de qualquer espécie, só beneficiará este fenômeno, quando respeitadas as leis que o rejam. O agricultor que plantar fóra de tempo, näo colherá. O operador que desdenhar as heis da assepcia, matará o paciente que lhe confiou a saúde. O militar que der de ombros aos seus soldados, perderá as batalhas que travar. O arquiteto que não contar com a resistência dos materiais, não construirá obra que dure. A natureza só se deixa dominar pelos que lhe respeitarem as leis.

O professor, pois, que, no ensino, não se inspirar nas leis da percepção e do raciocínio, jamais ensinará bem. A idoneidade da ação ensinante está na observância às leis que presidem à percepção e raciocínio dos adolescentes.

\section{Leis da Inteligência}

Estas leis são conhecidas. A explicação que convuria fazer delas, para serem bem compreendidas, exigiria um curso pausado e sịstemático. Não é possivel cogitar disto aqui. Limitemo-nos a referencias que bastem a quem já estiver mais ou menos ao par de como funciona a inteligencia humana, principalmente na sua fase construtiva.

Primeiro, lembremos as duas fórmas de adquirir cada pessôa os conhecimentos, que tenha. 
O que cada qual conhece, ou é por observação própria, ou é por ler e ouvir dizer. Deixemos a margem qualquer debate sobre idéias congênitas, ou a origem subjetiva do pensamento. Na infancia, na adolescencia, na juventude, na madureza, e, até, na velhice, não ha, ao que nos parece, para cada homem, mais que duas fontes aquisitivas de conhecimentos científicos: ou observação própria, ou observação alheia. E, para o homem em geral, uma só: a obser. vação. A origem primária dos conhecimentos é sempre a observação.

Mas a observação ultíma, no cérebro humano, o seu processo, por dois caminhos: a percepção e o raciocínio. Se o objeto do conhecimento está presente aos sentidos, prevalece a percepção. Se ausente, o raciocínio.

Examinemos, em súmula, ambos os dois. Em um e outro, ha dois fenômenos distintos: o mecanismo e a marcha aquisitiva.

O mecanismo se compõe sempre de três partes. È a marcha de número incerto.

\section{Leis da Percepção}

Exemplos, primeiro, da percepção.

Entrando numa sala escura, toco em dois objétos distintos. A impressão tactil do primeiro, pelo seu volume, sua fórma, sua aspereza, me faz perceber uma cadeira. Pela impressão tactil do segundo, percebo uma escrivaninha. Num e noutro caso, o mecanismo da percepção é constante e se compõe de três partes: a impressão atual do tacto, evocações de outras impressões, e a conciência de que estas e aquelas provêm da mesma realidade.

Mas como, dir-se-á, a impressão atual evoca atributos constitutivos da mesma realidade?

Por associações anteriores. Principalmente na meninice e na mocidade, vamos colhendo, a cada momento, noções de toda sorte, sobre tudo o que nos cerca. A mesma 
realidade, maiormente complexa, só a percebemos bem, depois de sucessivas observações, um a um, de seus aspectos, elementos ou relações. E', por exemplo, o conhecimento da árvore. Como o obtivemos? Nos primeiros anos da nossa existencia, uma árvore era, pouco mais ou menos, um tronco, folhas e raizes. Mas observações sucessivas nos fizeram ir avolumando a conciencia primitiva, até atingir a que hoje temos desta realidade. Aos vinte ou trinta anos, a noção da árvore é incomparavelmente mais compreensiva que a dos primeiros tempos. Então, basta, digamos, num deserto de areia, a visão longínqua de certa fórma no ar, para que se perceba uma árvore frondosa, a cuja sombra nos podemos talvez acolher.

Outro exemplo, para deixar bem claro a marcha aquisitiva da percepção. Certa pessoa, de quem não tivemos a menor notícia, nos é apresentada na rua, e logo se vái embora. Dela nos ficou, apenas, a noção vaga de uma criatura humana, masculina, bem apessoada, ainda moça, e pouco mais. Dias depois, porém, a encontramos de novo, e com ela trocamos dois dedos de prosa. A vivacidade do seu olhar, o tom da voz, certos gestos, a segurança das suas idéias, e outras impressões, aumentaram a noção que, desta pessoa, a princípio tivemos. Os encontros se sucedem, e, cada vez, melhor a conhecemos, na sua cultura, nos seus sentimentos, nos seus gostos, nos seus hábitos, no seu procedimento, no seu carater. Compare-se, então, o conhecimento que as sucessivas percepções nos deram, com a impressão inicial. Agora, por exemplo, apenas lhe ouvíssemos a voz, já esta voz evocaria todo o mais, que, aos nossos olhos, lhe constituem a individualidade.

Nunca é demais, aliás, ter-se presente que tanto na marcha aquisitiva, como no, mecanismo, a observação é a fonte originária das noções, dos conhecimentos, da verdade sobre seja o que for, que se perceba. A impressão inicial, que se tenha, de uma realidade complexa, é global, imprecisa, nem sempre exata, nem completa. As impressões parciais, que sucessivamente se vão recebendo, é que nos pro- 
porcionam um conhecimento mais compreensivo, mais verdadeiro, e mais claro.

\section{Leis do raciocínio}

Agora, exemplos de raciocínio.

Os conhecimentos que decorrem do raciocínio, já não recaem necessariamente sobre cousa presente. Sei, verbigratia, que o ar é transparente, por percepção imediata. Mas, sei, tambem, que sou mortal, não por percepção, pois que estou vivo, mas por conclusão deste raciocínio:

Sou homem.

O homem é mortal.

Logo, sou mortal.

E' o mécanismo do raciocínio dedutivo, o que, em lógica, se chama silogismo. Compõe-se de três partes: $10^{a}$ ) uma percepção atual, a premissa menor; 2.a) um conhecimento geral, a premissa maior; e 3.a) a conclusão. Da primeira se passa à segunda, em virtude de associações anteriores, cujos elementos são agora evocados por um dos aspectos da percepção atual.

O segundo fenômeno distinto do raciocínio é o que nos dá o conhecimento geral, que, muitas vezes, serve de premissa maior no silogismo. Como na marcha aquisitiva dos conhecimentos intuitivos, a marcha aquisitiva dos conhecimentos gerais se compõe de uma série de observações sobre cousas variadas, nas quais se generaliza o que ha de comum, de permanente, ou de constante. E', digamos, a verdade de que todos os homens são mortais. Como se adquire o conhecimento não do que $\mathrm{A}$ ou $\mathrm{B}$ foram mortais, por terem morrido, mas o conhecimento geral de que os homens são mortais?

Naturalmente, assistiu-se á morte de alguem, ou, pelo menos, viu-se o cadaver de pessôa que outrora se vira na exuberância da vida. $\mathrm{E}$ não só um, mas inúmeros casos 
como estes. Aqui, é um velho; ali, uma criança. Ora, homem; ora, mulher. Não importa a idade, o sexo, a cultura, a raça: onde quer que se observe uma criatura com as qualidades humanas, entre estas estará sempre a da mortalidade. A coexistência da humanidade e da mortalidade se gravam associadas, em nosso espírito, como sendo constante e inevitavel. Eis aí um conhecimento geral, que derivou de observações sucessivas, encaminhadas com lógica.

Repare-se, tambem, aqui, que, tanto no silogismo, como na inferencia, a observação é a fonte originária e exclusiva das verdades que se provam.

Em face destes sumários, cujos esclarecimentos requereriam estudos mais detidos, podemos assentar as conclusões seguintes:

Primeira, os conhecimentos, quer o intuitivo, como o da transparencia do ar, quer o discursivo, como o da atração universal, derivam da observação. Ou, por outras palavras, a observação é a fonte primária de seja qual for o conhecimento científico.

Segunda, o conhecimento, cada vez mais aproximadamente exato, da mesma coisa, se obtém na continuidade das observações do mesmo objeto e de outras em comparações com ele.

\section{Leis da análise}

Duas outras verdades sobre a percepção, e sobre o raciocínio se devem ainda pôr em evidência, como indispensáveis à compreensão dos processos de ensino. São as leis de anảlise.

Na marcha aquisitiva das percepções, ou na função in dutiva dos conhecimentos gerais,

- o que se repetir em cousas variadas que se observem, tende a ser objeto de um conhecimento próprio;

- e o que variar em cousas semelhantes que se percebam, tende, igualmente, a ser objeto de conciencia distinta. 
São as duas leis de análise, como fenômeno essencial, que é, na aquisição de conhecimentos.

Ha, sem dúvida, alem das análises, outros fenômenos apreciaveis no raciocínio e na percepção, atividades complexas, que compreendem a atenção, a memória, a linguagem, e, às vezes, a imaginação criadora, nas hipóteses com que se explora o terreno ao aparecimento das verdades.

\section{O princípio supremo}

Atentando-se mais detidamente no problema da aquisição de conhecimentos, chega-se, sem grandes embaraços, a um só princípio, que envolve as conclusões anteriores. $E^{\prime}$ o de que o homem só adquire de primeira mão conhecimentos cuja verdade se prove, observando por partes. Quando uma noção lhe é transmitida, o transmissor, por sua vez, só a poderia ter obtido por observação pessoal, ou por informações de quem saiba, no inicio, por observação pessoal. De modo que o grande princípio, que domina toda a atividade cognoscente das coisas neste mundo, é a observação por partes. A observação analítica é a fonte originária de seja qual for a verdade cientifica.

\section{A primeira norma didática}

E' chegado, então, o momento de encarar de frente o problema dos métodos de ensino.

o que, primeiramente, importa aos professores, é que seus alunos aprendam, isto é, adquiram conhecimentos.

Ora, a aquisição natural de conhecimentos se opera, observando por partes.

Logo, deve-se ensinar, fazendo observar por partes.

E' a mais profunda verdade em didática. 


\section{A segunda norma didática}

Mas além de adquirir conhecimentos, visa o ensino persuadir da verdade, e formar o espírito dos educandos.

Ora, a persuação da verdade e a formação do espírito resultam da orientação lógica e realista do trabalho mental.

Logo, ao se fazer observar por partes, cumpre encaminhar as observações segundo as leis lógicas do pensamento.

E' a segunda verdade por excelencia em didática.

Esclareçamos.

A observação dos fenômenos, para a inferencia de conhecimentos gerais, só chega, ou só pode ter probabilidades de chegar a bom termo, se forem respeitados os cânones lógicos. Ha muito já Stuart Mill os explicou à saciedade, e para todo o sempre. Os quatro métodos da indução: - o da concordancia, o da diferença, o das variações concomitantes, e dos resíduos, são o que ha de mais profundo na lógica dos homens. Sem a aplicação deles, não ha observação que abra caminho seguro às verdades gerais.

Os alunos, deante do que vão aprender, semelham o cientísta em face dos mistérios que tenta desvendar. A atividade dos alunos, se o professor não a pautar pelos cânones lógicos, será fatalmente manca. Mas se o professor a dirigir, inspirando-se nos processos do cientísta que investiga, ainda que com as abreviações e a segurança de quem já conhece o que vai ensinar, os resultados da como redescoberta que proporcione aos alunos, serão maravilhosos.

\section{Providências preliminares}

Preliminarmente não se dedignará o professor de tomar providências, para conseguir ou manter um ambiente propício ao ensino. Providenciará para que nada distráia, senão antes tudo concentre a atenção dos alunos. Promover boas condições de luz, calor, e ar, número limitado de alu- 
nos em cada classe, visibilidade perfeita do quadro negro, asseio geral das salas, das cortinas e do material, boa colocação dos alunos, e coisas semelhantes escapam, em rigor, ao problema do método.

Quando, porém, a atenção dependa do procedimento do professor, já se trata de método. E lhe cabe providenciar, ou proceder bem. Nada fará, primeiro, que possa distrair do assunto que explique, a atenção de seus alunos.

Algumas vezes, a linguagem de certos professores é cheia de reticências, de tiques nervosos, de cacoetes que abrem flancos a distração dos alunos. Alguns ficam a contar quantas vezes repete ele certas frases meio inconcientes, como não é?, compreendeu?, ein?. E da lição do professor lhes chegam, apenas, remotos ecos da voz sem sentido.

Outras vezes, a palavra do professor é mal ouvida, ou fanhosa, ou mal articulada. A desatenção e a indisciplina são consequencias naturais das suas deficiencias, se outras causas não houvesse, e ha.

\section{A primeira norma}

Mas admitamos que os fatores de desatenção e indisciciplina foram eliminados pela direção e pelo professor. $\mathrm{O}$ professor está deante de jovens, dispondo de material didático suficiente, senhor do assunto que vái explicar. Em que deverá consistir, então, a sua técnica?

Primeiro, e acima de tudo, cumpre-lhe pôr, em face de seus alunos, as realidades que vái ensinar. E' preciso fazê-los observarem por partes.

Não ha êrro mais lamentavel na escola, do que substituir $\mathbf{o}$ professor a realidade que vái dar a conhecer, pela sua pessôa, ilustre quiçá, mas que não é objeto da lição. $\mathrm{E}^{\prime}$ comum, e toda gente pode testemunhar este fato, interpor-se o professor entre o objeto de seu ensino e a inteligencia de seus ouvintes, dissertando-lhes em abstrato, como se estivesse preparando tarefas de cór. Nem sempre lo- 
gram os alunos compreender suas lições; mas as repetem na ponta da língua. Em viagem a países sul-americanos, nos conta Eduardo Prado de uma visita a um estabelecimento de ensino, onde assistiu a um interrogatório sobre história sagrada. "Perguntava, diz ele, uma jovem irmã de caridade a uma adoravel criaturinha de cinco anos, que sabia perfeitamente de cór a lição:

— "Que fazia Baltazar em Babilônia?"

E a resposta sem demora, na ponta da língua:

- "Entregava-se a toda sorte de prazeres sensuais".

Lembra este caso o episódio celebrado de certo exame de geografia numa escola primária. Perguntava o examinador, que, aliás, não exercia o magistério, ao melhor aluno da turma:

- Se descessemos num poço bem fundo até quasi ao centro da terra, lá em baixo sentiríamos mais, ou menos calor que na superfície?

Como o examinando ficasse sem atinar com a resposta, acudiu, em seu auxílio, a professora, repetindo a pergunta nos termos em que ensinara:

"Menino, qual é o estado do centro da terra?

E a resposta não se fez esperar magnífica:

"E' de fusão ígnea".

São deste náipe os resultados das lições de cór, sempre que o professor deixa de ter a técnica devida, interpondo-se entre o aluno e a realidade cognoscenda. No tempo que professei pedagogia na Escola Normal desta cidade, causticava eu, sem piedade, as lições de cór, como dupla tolice, consumada no professor, e a consumar-se nas suas vítimas.

A primeira norma técnica do método de ensino, repitamos, é a observação pelos alunos das realidades que vão conhecer.

Sempre que possivel, o objeto da áula será apresentado em si mesmo. Quer-se, por exemplo, mostrar a influência do sol na germinação das plantas. Em logar de uma descrição abstrata, que será logo esquecida, e não convence, jamais se delirá da memória a observação direta do fenô- 
meno, como fazendo o professor plantar, aos olhos dos alunos, algumas sementes de milho e feijão, umas à sombra, e outras ao sol. No fim de algumas semanas, a comparação dos dois crescimentos imprimirá, para sempre, no espírito adolescente, a noção da benéfica influência do sol na vida das plantas.

A apresentação da realidade á observação dos alunos pode ser tambem para o ensino de relações abstratas. Trata-se, digamos, do ensino da regra de três, da divisão proporcional, e noções de juros, em classe ainda primária. Martelará em vão o mestre-escola, se tentar pôr estas noções na cabeça de seus alunos, por meio de símbolos que figurem as realidades, aplicações de regras, e raciocínios ainda que apoiados em fatos. Mas faça o que, aquí mesmo nesta cidade, numa escola rural de Butantan, uma exímia professora realiza, nestes dias. Os alunos, em grupos associados, escolhem chão para arrotear; requerem a gleba que preferem; e, obtido deferimento, roçam, capinam, cavam, plantam, adubam e tratam carinhosamente os canteiros, sob o olhar dirigente da professora. Depois, vem o dia da colheita, e a distribuição do colhido em partes proporcionais aos gastos para a compra das sementes, do adubo, das ferramentas, e do trabalho de cada qual, seu tempo e rendimento. Em torno destes fatos, preparados com inteligencia, noções das mais úteis de matemáticas, vão surgindo com facilidade, palpitantes de vida, á mente da criançada alerta e alvoroçada.

Ha mais de sessenta anos, entre nós, ainda eu não era nascido, em parecer de 1882, já Ruy, sem ser professor de carreira, mas com a intuição profunda de seu gênio, rasgava, aos olhos do magistério brasileiro, o véu destas verdades eternas. E, antes dele, Pestalozzi, após Conrenius, mas sobretudo Pestalozzi fixou, em moldes imperecíveis, na intuição sensorial, o método por excelencia do ensino primário.

A intuição é aqui entendida como a presença das realidades cognoscendas aos sentidos dos estudantes. 
Quando esta presença não fôr possivel, como se me cumprisse dar a conhecer, aqui, agora, o rio Amazonas, restaria ao professor o recurso da projeção cinematográfica, ou da representação em miniatura, por mapas da região, em alto relevo, ou apenas em desenho. O cinema, a fotografia, o desenho, o alto relevo e processos congêneres são recursos aceitáveis de quem não dispuser da cousa em si, para ensinar, como deve. O cinema, hoje em dia, realiza maravilhas. Com o artifício, por exemplo, da câmara lenta, faz ver o invisível a olhos nus, como o crescimento das plantas. E muito mais ainda se póde esperar dele para a exata observação da natureza.

Dir-se-á que este preceito é, às vezes, de realização impossivel. Como, por exemplo, ensinar, por intuição, história? Reproduzir os fatos em cenas cinematográficas, como, àparte as fantasias, a história da secessão nos Estados Unidos, em "E o vento levou"?

Nem sempre é possivel, e, por certo, a amplitude e a fidelidade dos fatos deixariam muito a desejar. Ha mesmo fatos infotografáveis, episódios, se me abrem crédito ao neologismo, incinemáveis.

$\mathrm{E}$, mais do que história, como ensinar intuitivamente fenômenos jurídicos, matemática superior, filosofia? Não será inevitável, no ensino destas disciplinas, penetrar a fundo nos domínios da abstração?

Seria realmente forçar a mão, em tentativas estéreis, querer ensinar disciplinas desta natureza, por intuição imediata. O espírito humano vai-se formando do concreto para o abstrato, das impressões intuitivas, para as verdades discursivas. Não se compreende cultura humana, só com percepções de coisas concretas, ou seus atributos sensíveis, e relações recíprocas. O espírito que se civiliza, se eleva às regiões mais altas, mais abstratas, como as da matemática superior, da lógica, das ciências sociais, de teorias, como as sobre origem e evolução da vida, e do universo. Sempre que se trate de realidades inconcretizaveis, ou que não resultem imediatamente de coisas concretas, como, por análises, as 
abstrações elementares, força é recorrer á palavra para o ensino, como nesta conferência, em que deponho o que sei sobre como ensinar.

Alem disto, mesmo as cousas concretas, mas fóra do campo atual de nossa observação, e que, por carencia de meios, não possam ser representadas ao vivo, como fazê-las objeto de ensino, sem o emprego correntio da palavra?

Mas ái de quem se vale da palavra no ensino! Nas comunicações quotidianas dos homens entre si, na imprensa, na tribuna, nas conversações ao "pé da lareira", o uso da palavra não oferece maiores dificuldades. Mas, no ensino, ela é espada de dois gumes: tanto pode ser bênção, que eleva, como maldição, que perverte. Usada com arte, é capaz de maravilhas. Sem técnica, porém, não passarão de maravalhas os seus resultados.

Tiremos a limpo a diferença.

O verbo é, não ha dúvida, indispensavel no ensino, como instrumento que apresente á inteligencia dos alunos, realidades cognoscendas. A eficiencia didática da palavra, porém, não está na eloquencia, na fluencia, na verbosidade do professor. A palavra correntia, ou cintilante, póde agradar; mas nem sempre ensina. Só realizará o milagre da criação pelo verbo o professor que, com ele, evocar aos alunos imagens de realidades por êles conhecidas, para gerarem, mercê de combinações hábeis, conceitos novos, objeto do ensino a seu cargo.

Faço o que posso, por não merecer, nesta exposição, a pecha, que condeno, de verbalismo. Estou na impossibilidade material de trazer, aquí, aos que me atendem, as realidades em si, sobre que disserto. Mas envidarei substituílas bem, pela palavra no uso que posso. Evocando o que suponho conhecido pelos meus ouvintes, não só procuro dar-lhes a impressão clara do método e processos de ensino, como incutir-lhes a convicção de que tais processos e método se apoiam em bases científicas.

Mostremos como se póde ensinar bem em filosofia, ou em ciencia social. 
Trata-se, por exemplo, de esclarecer a concepção da lógica e da psicologia, o papel de uma e de outra no estudo da inteligencia. O raciocínio é objeto da psicologia e é não menos objeto da lógica. Mas qual o âmbito de uma, e o da outra? Ou, por outras palavras, que é lógica, e que é psicologia?

Poderiamos tentar o ensino por definições, compará-las entre si, analisá-las, fixar o sentido aos termos, opôr conceito a conceito, e, sempre dentro desse critério, concluir, e bem. Seria isto, porém, ter método de ensino, que valha?

Não nos parece. Por estes processos nos debateriamos numa algaravia bisantina, sem nenhum valor educativo. Criariamos, por cima, nos alunos, o horror aos estudos da lógica, como já é proverbial que tenham aos de gramática. E não sairiamos de um cipoal, numa espécie de bateboca doutrinário, sem dar à frente um passo que se aproveite.

Suponha-se, porém, que o professor, bem avisado, siga com arte outros rumos. Começará por lembrar aos seus alunos cousas por eles conhecidas, e combinará as imagens assim memoradas, de modo que gerem os conceitos das coisas desconhecidas, que ensina.

No caso, lembremos, para exemplificar, as funções do mecânico, e as do condutor de automóveis.

$\mathrm{Eu}$, por exemplo, sei guiar estes carros, mas não entendo nada de mecânica. O menor desarranjo do veículo, na estrada, me deixaria a pé. $O$ mecânico sabe montar $e$ desmontar, peça por peça, a máquina; em qualquer enguiço, um leve exame lhe revelará a causa, e, com ajustar um parafuso, ligar um fio, limpar uma vela, substituir ou limar uma peça, fá-lo pronto para andar, como novo em folha.

Se, porém, se quiser levar o automovel a um ponto predeterminado, já não é o mecânico o indicado, para imprimir direção ao automovel, mas o motorista. A função deste é guiar o carro. A do mecânico é aparelhá-lo, para funcionar bem. 
Semelhantemente com a psicologia e a lógica em face do raciocínio.

O psicologo conhece, peça por peça, o raciocínio; sabe como ele funciona em qualquer idade, quer se trate de inteligencia normal, quer de inteligencia desvairada, quer de gênio, quer de imbecil, homem culto, ou ignorante. Os conhecimentos, com suas variedades e suas leis, sobre o raciocínio são psicologia.

Quer-se, porém, na função do raciocínio, atingir a verdade sobre qualquer assunto. Quando supersticiosamente concluo que, por sermos treze num almoço, o mais velho ou o mais moço vái passar por desgraça iminente, a psicologia é perfeita. Mas a lógica foi sacrificada. O raciocínio que me sugere esta superstição, não se disciplinou, de modo que se verificasse a relação necessária entre o antecedente do convivio de treze e o consequente da desgraça para um deles. Bastaria aplicar o método da concordancia ou da diferença em fenômenos semelhantes, para tirar a limpo a inexistencia de causalidade entre um e outro fato. A atividade do raciocínio para descobrir as leis, para evitar os erros, desmontar os sofismas, provar, em suma, a verdade, tem de seguir certa direção, pautando-se por certas normas. Os cânones que disciplinam a inteligencia para atingir a verdade, são como a técnica do motorista que leva o carro aonde lhe apraz.

Tais cânones constituem a lógica. Lógica é a disciplina da inteligencia para descobrir ou provar a verdade.

Eis aí como o verbo, revivendo realidades conhecidas, a do mecânico e a do condutor de automóveis, põe em evidência, por analogias ou semelhanças, a função da psicologia e a da lógica no mecanismo do raciocínio. Invocações, comparações, combinações de imagens criam, no espírito do aluno, o que lá não existia, e se quer que exista.

Já Socrates, ha mais de dois mil anos, nos deu o modelo imperecivel da palavra, como instrumento de ensino.

Outro exemplo, no ensino do direito. Pretendo ensinar a uma classe de moços o que é representação política, como 
um passo para se compreender o regimen representativo. Admitamos haver, aqui, alguém que o não conheça, ou não lhe tenha apanhado, ainda, a estrutura intima, no que ele tenha de fundamental e irredutivel.

A palavra lhe vái revelar a verdade sem escolasticismo, que tudo confunda.

Trata-se de povo livre, que, para dirigir os seus negócios coletivos, delega o exercício de sua soberania a determinados cidadãos. Certo, os alunos a que se intente incutir a doutrina, não são crianças de jardim da inflância. Já têm apreciável desenvolvimento intelectual, regular cultura, e hábitos de disciplina mental.

Nada mais facil, então, que lhes recordar realidades por eles provavelmente conhecidas, para lhes doutrinar com verdade e clareza sobre o que seja representação política.

Lembrar-lhes-á o professor, por exemplo, o caso de alguem que, por morar longe de propriedade agrícola, que possua, se vê na contingência de cometer a outrem a administração dela.

Mas como procede?

O proprietário, primeiro, escolhe o administrador. Se, em vez de escolha sua, valesse imposição alheia, quem é que seria o proprietário? E a que título poderia outrem impôr ao senhorio, administrador para o que é seu? Toda gente está farta de saber que escolhas desta natureza só devem ser feitas pelos donos, sem interferencia de extranhos, que lhes subtráiam o arbítrio.

Mas não é só. O proprietário agrícola dá instruções ao administrador que contrata; determina-lhe como quer, em linhas gerais, a gestão que lhe comete, de sua herdade.

Em terceiro logar, de quando em quando, chama a fala o seu comissário. Este lhe presta contas de como vái dirigindo a empreza que the foi confiada.

$E$, por fim, se o comitente se dá por satisfeito, vái periódicamente lhe renovando o mandato. Se, porém, discorda da administração que o seu escolhido fez, ou está fazendo, claro está que o exonera, ou não lhe renova o encargo. 
$\mathrm{E}$, assim, cọm instituir alguém administrador para gerir propriedade sua, não perde o direito ao que é seu.

Transportemos o caso para a vida política, numa sociedade que se governe a si mesma. Não podem os indivíduos todos, que a formam, tomar conhecimento, dia a dia, dos negócios coletivos que surgem, dar a cada um deles a solução conveniente, providenciar a defesa coletiva que se imponha, e promover o bem comum, a que todos aspirem. Então, tendo, por assim dizer, a propriedade de si mesmo, o direito de se governar sem subordinações ao arbítrio de ninguem, o povo elege, sem tutores, ou curadores, mandatários seus, para gerirem os interesses de sua vida comum.

Dá instruções gerais aos seus eleitos sobre o que podem ou não podem fazer. Estas instruções são exaradas em constituições solenes, e nas leis, são renovadas na voz da imprensa e da tribuna, por onde o povo respira, e exerce sua liberdade de opinar.

$\mathrm{E}$, de tempos a tempos, chama-os a contas, responsabilizando-os pelo desempenho que derem ao mandato para governar. Esta responsabilização é simples. Se o povo estiver de acôrdo com o que tenham feito, ou estejam a fazer, lhes renova a incumbencia para novos períodos. Se não, os exonera do encargo, findo o mandato, e escolhe, para substitui-los, outros de sua confiança atual.

Chegou, então, o momento de concatenar o professor, com estes e outros elementos, a matéria que explica, o seu histórico, se valer a pena, as variações que configurem melhor o assunto, a lei positiva que, entre nós, o consagre, o ideal para onde caminhem os sistemas realizados ou propostos. As críticas, ou as apologias podem, nessa altura, ser feitas com real proveito, desde que delas sejam chamados a participar os alunos. Dirão o que aprenderam ou sabem, exercitando, para o futuro, a sua liberdade de crítica, contanto que argumentem com lealdade, com imparcialidade, com o desejo de aprender. 
Depois disto, toda a classe ficará ao par dos elementos irredutíveis e dos accessórios na representação política, sem a qual não ha democracia, senão de beiço, ou no papel.

Parece-nos que, por este processo, a palavra não obscurece, não elimina, no ensino, as realidades que se explicam. Antes, as trazem presentes, não em si mesmas, é claro, mas nas imagens do que já é conhecido, para sugerirem, em combinações hábeis, o conceito exato da coisa nova, que se ensina.

\section{A segunda norma}

Até aquí, temos mostrado cânones a cuja luz se deve inspirar o professor, para pôr os alunos em presença do objeto de seu ensino. Mas a apresentação das realidades cognoscendas não realiza o milagre de se fazerem conhecidas por simples ação de presença.

Cabe, agora, aos alunos observá-las por partes. Não como lhes parecer bem ou melhor. Mas sob a direção do professor, sem a qual não alcançariam o objetivo proposto do ensino. E esta direção tambem não é arbitrária para o professor.

Em que preceitos, de ordem científica, se ha de, então, inspirar o professor, para que os alunos possam observar com lógica, e adquirir conhecimentos exatos, se convençam da verdade que haja nestes conhecimentos, e se habituem em consequencia a investigar por si sós?

Tenha o professor, em primeiro logar, o tino de não esquecer nunca os fins do ensino a seu cargo. Não só transmitir conhecimentos ou informar. Mas fazer que os discípulos tenham a conciencia da verdade no que aprendem. E de tal sorte que, em consequencia, os educandos se tornem cada vez mais capazes de aprender por si sós.

Em segundo logar, cabe aqui, ainda em preliminar, o exame de uma dúvida culminante. E' a de saber se não varia o método, com o gráu de ensino. Um para o primário. Outro, para o secundário. E outro para o superior. Pelo 
menos, três métodos de ensino, parece que devem existir, segundo o desenvolvimento mental, e a soma de conhecimentos que os alunos tenham.

Eu não me alisto, por convicção já antiga, que não me parece mudavel, entre os que admitem a multiplicidade de métodos de ensino. Estou persuadido, e não de hoje, da sua unidade. O que varia, são os processos de ensino crm que se atendem, pelo menos a dois fatos inegaveis: o desenvolvimento desigual da inteligencia dos alunos, e o gráu de preparo geral e específico, que já tenham. Mas estes dois fatos não destroem o que ha de profundamente o mesmo na atividade cognoscente. $O$ princípio dos princípios é sempre o mesmo: a fonte primária dos conhecimentos científicos é a observação. Não importa a idade, o gráu de inteligencia, ou de cultura. A observação é a matriz originária dos conhecimentos científicos. Logo, quem quizer ensinar bem, tem de fazer observar. Eis a unidade fundamental dos métodos didáticos.

Mas observar o que, e como?

Certo, observar, antes do mais, o que fôr accessivel ao entendimento dos escolares. Ninguem se lembraria de ensinar a autolimitação da soberania, a teoria da relatividade, ou o fundamento da indução lógica a crianças de escola primária. Nem mesmo multiplicação, em qualquer idade, a quem não souber somar. Nenhuma lição nova antes de bem examinado se o que lhe fôr propedêutico, já está bem assimilado pelos alunos.

O desenvolvimento mental e a soma de conhecimentos que os alunos já tenham, são fatos que o professor precisa considerar, para saber o que, e como ensinar.

A seriação das matérias, em rigor, escapa á alçada do professor, e, pois, do método de ensino. E' missão da lei, ou do planeador geral da escola.

Mas a graduação de cada assunto da aula já é matéria atinente ao método. O mesmo tema, como, por exemplo, a independência do Brasil, pode ser ensinado, com amplitude maior ou menor, a crianças de doze anos, como a ra- 
pazes de dezoito. Mas falhará no método o professor que não graduar a extensão do que vái ensinar, com a capacidade de compreensão, e o gráu de resistencia física dos seus alunos.

A capacidade de compreensão, além de ser dom da natureza, varia com a idade, a cultura e o adestramento. E' preciso contar, até, com as diferenças individuais na predominancia deste ou daquele sentido. Crianças ha auditivas, estas visuais, aquelas tácteis-motoras. As primeiras aprendem com facilidade o que ouvem, por lhes ser mais facil a atenção auditiva, e mais constante a memoria auditiva. As segundas preferem ver, e as terceiras fazer. Como, no ensino coletivo, deve haver de tudo, não deixará o bom professor de, na observação que proporcione aos alunos, faze-los ouvir, ver, palpar, e realizar, sempre que possivel.

O gráu de resistencia física de cada aluno, andaria mal o professor que não o tomasse em consideração, para the não prejudicar a saude. Para além da capacidade de resistencia, todo o esfôrço importaria em fadiga. Não só o esfôrço do aluno na disciplina a seu cargo, como nas demais. $\mathrm{E}^{\prime}$ o que sucederia se o professor desse aos seus alunos trabalhos de que sejam capazes, sem atender aos deveres que eles tenham nas outras cadeiras. E' o mesmo erro dos programas oficiais sobrecarregados, como se o fim do ensino fosse fabricar sábios.

Mas, além da qualidade e da quantidade do ensino, cuja determinação e graduação obrigam a observância de certo número de regras técnicas, como ha de encaminhar o professor a observação que cumpre aos alunos? Ou, d'outro modo, se a palavra supre a presença objetiva da realidade, como ha de combinar as imagens de realidades que tenham observado, para thes dar a conhecer realidades novas, objeto de seu ensino?

Já o professor conhece a capacidade média, e o preparo geral de sua classe. $O$ professor de verdade desce, sempre, até aos seus alunos, para que possam eles elevar-se, um dia, até ele. As suas maneiras de ensinar, ou seus processos di- 
dáticos se devem inspirar no de que forem capazes os seus alunos, no seu desenvolvimento mental, no gráo de sua cultura, nas suas variações individuais, nas suas possibilidades em suma, e nunca no que deveriam ou poderiam ser.

Estão eles, porém, em face das realidades, para observá-las. Ou, pelo milagre de seu verbo, o professor as trouxe á presença deles. Como ha de o professor, então, daqui em diante, dirigir a observação, o estudo, o trabalho de seus alunos?

Já sabe que seria erro interpor-se entre os alunos e o assunto das lições, observar por eles, como se fossem estes auditores passivos do que expõe.

0 que lhe cumpre é ensejar a que os alunos aprendam por esfôrço próprio à luz dos métodos lógicos.

Vejamos como, ou sob a inspiração de que leis.

Vái-se, por exemplo, ensinar a ler. O ensino pelo be-a-bá não seria a apresentação da linguagem real, que, nas suas expressões mais simples, já são frases e palavras. Mas elementos abstratos.

Apresente, porém, o professor aos seus analfabetos palavras de coisas concretas, que eles conheçam, ou sentenças breves, que exprimam realidades vividas por eles. Escreva, por exemplo, no quadro negro, a palavra cadeira, cujo sentido lhes é familiar. Depois, a palavra cama, não menos conhecida. Em seguida, a frase: o cavalo corre. Uma historieta foi contada, para despertar o interesse geral. $\mathrm{E}$ da historieta sairam as três palavras: cadeira, cama, cavalo. Começam elas pela mesma impressão visual e auditiva expressas em $c a$.

Não é preciso mais, para que este elemento ressalte e se analise. A sua reiteração em palavras variadas atraem mais vezes a atenção dos aprendizes. E, segundo a lei de análise, já mencionada, o que se repete em coisas variadas que se observem, tende a ser objeto de conciencia autônorna. A representação gráfica da sílaba $c a$ passa a ser conhecida a parte. A continuação do processo termina por fazer analisar grande número de sílabas, e, sem demora, as letras. 
Por esta fórma os alunos aprendem a ler, observando por partes, do concreto para o abstrato, da sentença para as sílabas e as letras. E não no sentido inverso das letras para as silabas, por soletração, para se chegar ao conhecimento das palavras ou das sentenças. A observação logo de entrada de frases simples, de sentido completo, começa por não mutilar o fenômeno da linguagem que os alunos observam, como se aprendessem pelo processo do bê-a-bá, e abre caminho, rápido e suave, vivo e interessante, ao aprendizado inteligente da leitura, compreendida sempre.

$\mathrm{O}$ encaminhamento que o professor imprime às observações dos alunos, consiste em sucederem-se de tal arte as realidades observadas, que os alunos analisem espontaneamente, por si mesmos, e não por ato da vontade, mas por força de leis inexoraveis.

Outro exemplo, o ensino da taboada. A tradição é o suplício da decoração abstrata. No entanto, facil é fazer observar coisas variadas com elementos ou traços idênticos. A identidade parcial de coisas diferentes passa a ser objeto de conhecimento próprio. Digamos que o professor põe, ante os olhos da criançada interessada, grupos de laranjas, de maçãs, de palitos de fósforos, de bolinhas de vidro, e outros objetos. Faz observar que dois grupos iguais, de cinco laranjas cada um, somam dez laranjas. Dois grupos iguais de cinco maçãs fazem dez maçãs. Dois grupos iguais de cinco bolinhas de vidro inteiram dez bolinhas de vidro. Não demorará a impor-se ao espírito dos aprendizes que dois grupos iguais de cinco objetos, sejam quais forem, são dez objetos. Ou duas vezes cinco, dez. Chega-se à norma abstrata, a regra geral, observando sucessivamente, com direção habil, casos concretos variaveis, nos quais alguma coisa haja de comum.

A direção didática consistiu em ensejar o professor a que as observações dọ alunos girassem, por força das cousas, no seu espírito, a noção genérica, a regra abstrata, que se pretenda ensinar. 
Dir-se-á que isto é possivel apenas na escola primária. Nenhuma aplicação tem no ensino secundário, e, muito menos, em escola superior.

Erro imenso. As leis que presidem á aquisição de conhecimentos, são as mesmas no homem, em qualquer idade. O que varia, à parte fatores hereditários, é a compreensão dos que aprendem, em virtude da idade vivida, do preparo adquirido, e da experiencia pessoal. Estas variações determinam variações de processos. Mas sem abrir mão do princípio geral, que unifica os processos num só método.

Vejamos em casos concretos.

Primeiro, na escola secundária, numa lição de química. Proporciona o professor aos alunos a experiencia da decomposição da água em hidrogênio e oxigênio. Viram fazer, ou fizeram a experiencia. Quantas vezes a repitam, sempre a indução é a mesma: a água não é corpo simples, decompõe-se em hidrogênio e oxigênio.

E' agora uma aula de latim. Quebrou o professor os moldes rotineiros: o de encetar o ensino de latim por declinações e conjugações decoradas. Isto nunca foi saber ensinar. Antes, ocasiona o professor a que os alunos observem a língua latina. Algumas frases latinas bem fáceis são apresentadas á observação dos estudantes. A tradução é feita, reparando os escolares na variação das terminações dos substantivos, para exprimirem as funções lógicas de sujeito, de objeto direto, de indireto, de complemento restritivo, de adjuntos circunstanciais.

A análise lógica é cultura sem a qual ninguém aprende bem latim, sobretudo como língua morta. Se o professor não verificar os conhecimentos de seus alunos em análise do pensamento, e se não se certificar de que a sua fraseologia é. entendida pelos alunos, não será jamais eficiente; sua classe será, por defesa própria, naturalmente indisciplinada, e ele máu professor, ainda que regorgite de sabedoria em letras latinas. Dê, porém, a traduzir aos seus alunos sentenças latinas, a princípio as mais simples, e, progressivamente complicadas. Faça-os observarem as terminações 
características, aquí do acusativo, como objeto direto dos verbos transitivos, ou atributo do verbo ser; alí do genitivo, como complemento que restringe a estensão do substantivo, e assim por diante. Quando já tiverem cabedal consideravel de observações, eles mesmos, os alunos, induzirão, encaminhados pelo professor, as normas das declinações dos substantivos. E assim para o resto. As aulas serão interessantes, a classe disciplinada, e os benefícios que se apregoam, do ensino do latim, em disciplina mental, serão colhidos.

Numa aula de matemática, a lição do dia é a relação entre a circunferencia e o seu diâmetro. Se os alunos compararem, concretamente, varias circunferencias com os respectivos diâmetros, verificarão, sempre, a constancia da relação expressa em 3,1416. Seria isto um processo intuitivo sensorial, facilmente aplicavel até na escola primária.

No ensino secundário, porém, os alunos já têm maior capacidade mental, e certa soma de conhecimentos gerais, que lhes permitem raciocinar com segurança nesta matéria. De dados hauridos em observações atuais extráem verdades novas, a que aderem. Sobre aprenderem, desenvolvem, nestes raciocínios práticos, a sua capacidade de aprender. Em vez de medirem, uma a uma, as circunferencias, tomando por unidade os respectivos diâmetros, demonstram a tese.

Sabe-se que a demonstração é um encadeamento de silogismos. Cada um destes se arma com uma premissa menor, que é percepção atual, ou hipótese aceita; uma premissa maior, que a premissa menor evoca, mercê de associações havidas em conhecimentos anteriores, e uma conclusão, que será aproveitada, para armar o silogismo seguinte. E assim até chegar-se à prova da verdade que na tese se enuncia.

O método, aquí, consistiu, primeiro, em fazer o professor que os alunos observem realidades, das quais se vão extraindo as premissas menores, e, segundo, encaminhar seus raciocínios, no sentido da tese. 
A prova deve ser feita pelos alunos. O que cabe ao professor, é apenas proporcionar observações convenientes, e encaminhar, segundo leis mentais, a demonstração lógica, que os alunos farão.

Vale a pena insistir neste aspeto do problema. Sempre lamentavel a didática que produz em certos alunos horror invencivel à matemática.

Retrilhe-se a hipótese num caso concreto. Quer-se dar a conhecer, já na escola secundária, a divisibilidade exata da soma pelo número que lhe dividir, sem deixar resto as parcelas.

Intuitivamente poder-se-ia fazer observar duas, três, dez, cem hipóteses diferentes. Verificar-se-ia, em cada hipótese, que, se um número dividir exatamente as duas, as três, as quatro, ou quantas forem, as parcelas de uma soma, tenham elas o valor que tiverem, estes números dividirão, sem deixar resto, as respectivas somas. Então, espontaneamente, segundo a lei de análise, a unidade na variedade, fica-se inteirado de que, independente do número de parcelas, ou do valor de cada uma delas, o número que dividir, sem deixar resto, as parcelas de uma soma, dividirá exatamente esta soma.

Mas, em logar de seguirem os alunos o método lógico da indução, poderiam, recorrendo à dedução, chegar ao mesmo resultado. Figuraria o professor, no quadro negro, e cada aluno em papel, a lapis, uma hipótese genérica, adequada. O número $d$, por exemplo, divide, sem deixar resto, as parcelas $a$ e $b$. Vái-se demonstrar que o número $d$ dividirá, sem deixar resto, o número $S$ soma de $a$ mais $b$.

A primeira hipótese é a premissa menor do primeiro silogismo: dividindo-se $a$, por $d$, o quociente é número inteiro, que se pode representar por $q$. Mas esta hipótese evoca naturalmente uma norma já sabida, a de que, nas divisões exatas, o dividendo é igual ao divisor pelo quociente. Logo, $a=d q$. A segunda hipótese, pelo mesmo processo, leva os alunos à conclusão de ser $b=d q^{\prime}$ ! 
O papel do professor, até agora, foi o de orientar o raciocínio dos alunos, e não raciocinar por êles.

Prosseguindo neste papel, fal-os-á somar as duas igualdades: $\quad \mathbf{a}=d q$, e $\mathbf{b}=d q^{\prime}$. Chamar-lhes-á a atenção para a existencia, deante deles, de duas somas de quantidades iguais. Ora, é axiomático que somas de quantidades iguais são iguais entre si. Logo, a primeira soma é igual à segunda.

O professor, para chegar à tese, fará notar que, no segundo membro da última igualdade, se acham multiplicados o numerador e o denominador da mesma fração pela mesma quantidade: $d$. Ora, não se altera a quantidade que se multiplique e se divida pelo mesmo número. $\mathrm{E}$ os alunos concluirão, por si mesmos, a um simples olhar: que $s$ dividido por $d$ é igual à $\mathrm{q}+\mathrm{q}^{\prime}$.

Por fim, observarão os alunos, sempre orientados pelo professor, que a soma: $q+q^{\prime}$ é número inteiro, por serem inteiras as suas parcelas, quocientes das divisões, por hipóteses, exatas, de $a$ por $d$, e $b$ por $d$. Logo, $d$ dividirá $S$ sem deixar resto. Isto é, o número que dividir as parcelas de uma soma, sem deixar resto, dividirá exatamente esta soma.

A atividade do aluno aquí já não foi indutiva, mas dedutiva, e a ação do professor consistiu em fazer seus alunos observarem certas realidades, figuradas em hipóteses, evocar conhecimentos associados com o que observam, para irem concluindo, até a prova final da tese.

Em nenhum momento da aula, foram os alunos reduzidos a simples ouvintes, ou videntes do que o professor fizesse.

Subamos ao ensino superior.

E' numa escola de medicina, numa aula de clínica. $O$ objéto da lição é o diagnóstico e a terapêutica de certa moléstia. Poderia o professor dividir muito bem a sua exposição doutrinária, e dissertar sobre o caso, em aula. Os seus alunos seriam apenas ouvintes, e sairiam, por certo, da aula encantados, pela fluência oratória do professor, sua eru- 
dição admiravel; mas incapazes de qualquer ação profissional.

Leve, porém, o professor os seus alunos a um hospital, onde os faça observarem, em vários pacientes, a moléstia cujo diagnóstico e terapêutica vái ensinar. Poderá ter feito uma exposição prévia, preparatória, ou a fará depois, ou à medida que as observações forem sendo registradas. Como cientista, ou perito, já o professor teve ocasião de observar e curar doentes da moléstia, sobre que versa a lição. Por eliminação ou produção de antecedentes, ou concordancia de causas e efeitos, no desenvolvimento da moléstia, já logrou apanhar a lei sobre o tratamento adequado.

Se não fosse deshumano, poderia o professor repetir, para observação dos alunos, a sua experiência. Então, os seus discípulos, através de tratamentos errados, e tratamentos certos, redescubririam a lei. Mas uma das vantagens do ensino está justamente em evitar os erros inúteis, o empirismo, abreviar o processo da indução lógica, e fazer chegar com segurança à verdade que se ensina. Devem dar com a verdade, através de observações bem dirigidas, e não por exposições frias e dogmáticas, em que não passem de meros ouvintes. Antes, fará o professor que seus discípulos: percebam os sintômas, descubram a causa, acompanhem a marcha da moléstia, e verifiquem os efeitos do tratamento. $\mathrm{E}$ aprenderão assim a diagnosticar sem erros, e a receitar, segundo suas ou alheias observações. Não haverá, depois disto, discípulo que se esqueça da relação de causalidade entre o tratamento ministrado, e a cura operada.

Remataria, nessa altura, o professor a lição, doutrinando em exposição clara, dividida logicamente a matéria, discutindo as várias interpretações, resolvendo erros aqui, assinalando acertos acolá, prevenindo sobre diferenças individuais, e concluindo as linhas mestras do procedimento clínico.

Sempre, proporcionar aos alunos observações apropriadas, abreviando-lhes o trabalho, encaminhando-os para o 
fim em vista, isto é, no meio da variedade dos casos que observem, inferir ele, ou fazer que os alunos infiram a lei ou as leis em estudo.

Agora, é uma escola de direito. O método do professor no dirigir o trabalho dos alunos é aqui mais árduo. Terá de recorrer quasi sempre à palavra, para evocar as realidades sociais, que não póde materializar, ou submetêlas a experiências. O registro dos fatos tão fugidios e erradiços, as estatísticas por vezes tão fantásticas, o testemunho sempre tão claudicante, os documentos indecisos, e nem sempre de autenticidade inequívoca, são elementos de que, afinal, não prescinde o professor de sociologia, de direito, de economia, de moral, para encaminhar as observaçôes de seus alunos, de modo que atinem com as relações constantes entre antecedentes e consequentes nos fenômenos em estudo.

As preleções abstratas, as conferências por mais eloquentes, os discursos bonitos podem embalar a imaginação curiosa dos discípulos, mas não. persuadem aos que amem sobretudo a verdade. $O$ método realmente exige, do professor, fazer que os alunos observem os fatos, vejam o que haja de invariavel entre os antecedentes e os consequentes nos fenômenos complexos, e infiram, então, as leis, as verdades. Isto no campo iluminado das doutrinas.

Se o que se quer, porém, é explicar a lei jurídica positiva, o método ainda não varia no que tem de substancial. A lei positiva que disciplina certo fenômeno social, só será prestavel, se consagrar a lei científica sob que este fenômeno se desenvolva. Pelo estudo da lei científica, se aquilata o valor da lei positiva, o seu alcance, o seu préstimo, as suas aplicações úteis.

Casos ha de si tão complicados, nas ciencias morais e juridicas, que o debate é indispensavel, para deslindar dúvidas inevitaveis. A interpretação dos fátos ou da experiência, em fenômenos intrincados, pode gerar opiniões opostas. E' o que se nota comumente em política, em moral, em religião. Nesse terreno, a direção que o professor 
imprime ao trabalho dos alunos, é eriçado de dificuldades imensas.

As realidades sociais, que traz ao tablado do ensino, por serem, em regra, fenômenos enredados de elementos que desnorteiam, todo o esforço dirigente dos professores é pouco, em primeiro logar, para que não sejam êles mutilados, ou se reduzam a partes que se podem tomar pelo todo. O desprezo de alguns dos aspectos ou elementos dos fenômenos, é o quanto basta para as opiniões apressadas e suspeitas de parcialidade. Os antecedentes, os consequentes, as circunstâncias que matizem os fenômenos, nem sempre é facil trazê-los à inteligência crítica dos estudantes. Por outro lado, pode faltar ao professor que não saiba defender-se do fanatismo, aquela imparcialidade científica, que dignifica o magistério. $\mathrm{E}$ os seus preconceitos, as suas idéias arraigadas, os seus hábitos sentimentais podem arrastá-lo a deformar as realidades, em prejuizo do progresso da verdade, nas ciencias sociais.

Ensinar bem disciplina social, e, principalmente, moral, é, realmente, obra digna dos deuses.

\section{Súmula Didática}

Mas é tempo de rematar estas considerações, já tão alongadas, sobre as técnicas do ensino.

A norma suprema, para ensinar bem, ou aprender bem, é fazer o professor que seus alunos observem as realidades cognoscendas.

Para ocasionar esta observação, deve o professor apresentar as cousas que ensina, aos sentidos atentos dos que vão conhecê-las.

Quando forem excessivas as dificuldades para a apresentação em si das realidades que se explicam, ha o recurso da sua apresentação pelo desenho, pela fotografia, pelo cinema, pelos símbolos. 
Se, pela natureza das coisas, não fôr possivel a presença do objeto do ensino aos sentidos, ainda que figurado, terá, então, o professor de recorrer à palavra.

Mas a palavra só não decai em verbalismo esteril, quando logra despertar, no espírito dos alunos, imagens do que já conhecem, para lhes sugerirem, por semelhanças, por analogias, por combinações hábeis, os conhecimentos novos, que se querem dar.

Para que a palavra realize este milagre, deitará o professor uma sonda nas camadas de cultura de seus alunos, e tomará em consideração a sua capacidade atual de aprender. Sem estes entendimentos prévios, a palavra é sôpro que o vento leva.

Presente em si, em representação, ou por milagre do verbo, ao espírito dos estudantes o objeto das lições, a técnica do ensino está em dirigir o professor o trabalho dos alunos, segundo leis que presidem à percepção e ao raciocínio. São leis de análise e leis de associação de idéias, leis de indução lógica, e leis de dedução e demonstrações matemáticas.

Se tudo isto não pode ser razoalmente desconhecido, como admitir professor, com técnica impecavel, sem conhecer a ciência dos métodos? Não basta o empirismo, que costuma gerar a rotina perniciosa ou mal aventurada. E' preciso elevar-se às leis e princípios, como em qualquer profissão de valor.

Ademais, requer-se, no professor, a existência de pelo menos três condições.

Primeira, saber de verdade a matéria que ensina. Não conhecê-la toda, evidentemente. Mas com perfeição o que lhe cumprir ensinar.

Segunda, guardar imparcialidade na doutrinação que tenha de fazer. Ha, sem dúvida, disciplinas, como aritmética, onde não cabe o debate, ou como geografia, ou física elementar, onde as explicações não suscitam em regra opiniōes contrárias. Mas algumas ha, como as ciências sociais, ou filosóficas, em que o debate é imprescindivel para 
o esclarecimento da verdade. Nestas, é que a imparcialidade do professor é posta à prova rude.

Terceira, clareza. E' a suprema excelência na técnica do professor. A clareza desperta e sustenta o interesse, e assegura, quasi por si só, disciplina na classe. Não deriva a clareza tanto da usualidade na linguagem que se empregue, como de sua concordância com a inteligência e a cultura dos alunos, e de sua propriedade com o objeto do ensino. Se, a clareza é, em geral, o toque de perfeição da linguagem, na técnica do professor é o seu maior merecimento. Palavra obscura é sinal infalível de ausência de técnica no ensino.

Mas quem sabe o que ensina, e é imparcial, se sabe ensinar, é porque é naturalmente claro. E quem não tiver clareza em sua linguagem, ainda que se esmere em erudição, ou pompeie de sábio, não saberá primar no ensino. No professor, a clareza é o dom supremo de sua palavra, par a par com a ciência em que seja mestre, e a imparcialidade que lhe é ponto de honra. 